\title{
The dynamics of the growth of firms: evidence from the services sector
}

\author{
Blandina Oliveira $\cdot$ Adelino Fortunato
}

Published online: 30 April 2008

(C) Springer Science+Business Media, LLC. 2008

\begin{abstract}
Using a dynamic panel data model with serial correlation in the error term, the purpose of this paper is to examine if Gibrat's Law can be rejected for the services sector as it has been for manufacturing. The aim of this paper is also to improve the understanding of the empirical determinants of firm growth by extending the literature to include a new variable related to foreign participation. In addition, and based on recent developments in the growth of firms, our analysis also includes the role of the financial structure. The sample used is an unbalanced panel data set that includes all size classes, including the smallest surviving firms, from the Portuguese service sector over the period from 1995 to 2001. Applying the GMM-system estimator our findings suggest that Gibrat's Law is rejected for the services firms. In addition, the results also indicate that firm growth is mainly explained by firm size and age. These results have significant policy implications.
\end{abstract}

Keywords Firm growth $\cdot$ Panel data $\cdot$ GMM estimators $\cdot$ Services

JEL classification $\mathrm{L} 11 \cdot \mathrm{C} 23 \cdot \mathrm{L} 80$

\section{Introduction}

Most influential surveys on intra-industry dynamics ${ }^{1}$ have reached the conclusion from a rich body of empirical evidence, spanning numerous countries and time

\footnotetext{
1 See for example Jovanovic (1982), Geroski (1995), Sutton (1997), and Caves (1998).

B. Oliveira $(\bowtie)$

Superior School of Technology and Management (ESTG), Polytechnic Institute of Leiria, Morro do Lena-Alto Vieiro, Apartado 4163, 2411-901 Leiria, Portugal

e-mail: blandina@estg.ipleiria.pt
}

\section{A. Fortunato}

FEUC and GEMF, University of Coimbra, Av. Dias da Silva 165, 3004-512 Coimbra, Portugal 
periods, that firms' growth rates decrease with firm size and firm age. Most of these studies, however, are based only on cross-section models applied to the manufacturing industry. Dunne et al. (1988, 1989) and Audretsch et al. (2004) emphasise that one of the greatest impediments to examining this relationship has been the lack of access to longitudinal data sets. This shortage of data has been even more lacking in the service sector. This factor could explain why virtually all knowledge about the validity of Gibrat's Law is from manufacturing. But it is still an open question whether the growth dynamics for a firm in the services sector simply reflects that in manufacturing industry, since little is known on this, but the policy implications are significant (Audretsch et al. 2004).

The purpose of this paper is to see if Gibrat's Law can be rejected for the services sector as it has been for manufacturing. We consider the services sector because it has been insufficiently studied, plays a key and increasingly prominent role in the economy and is also responsible for net job creation. The aim of this paper is also to improve understanding of the empirical determinants of firm growth. Our work contributes to this strand of research in terms of the sample, variables and methodological issues used. First, we consider a sample of services firms only, as some earlier studies have done. However, our sample is an unbalanced panel data set that covers all size classes, including the smallest surviving firms. Second, we introduce a new variable related to foreign participation. In addition, and based on recent developments in firms' growth, our analysis also looks at the role of the financial structure. Third, we use a univariate and multivariate dynamic panel data model with serial correlation in the error term. Finally, we estimate these models with the GMM-system developed by Blundell and Bond (1998).

The paper is structured as follows. The next section presents a survey of the theoretical literature and empirical evidence on firm growth, as applied to the services sector. In the context of panel data models, Sect. 3 outlines the model used to summarize the growth process and the testable hypotheses, while Sect. 4 presents the econometric methodology used. In Sect. 5 the sample, variables and the summary statistics are described, whilst in Sect. 6 the empirical findings yielded by the GMM-system estimator is displayed and discussed. The final section contains the conclusions and some policy recommendations.

\section{Literature review}

The hypothesis that the growth of each firm in each period is independent of its observable characteristics, including size or past growth, was first developed by Gibrat (1931), and later became known as the Law of Proportionate Effect (LPE). ${ }^{2}$ According to the LPE, growth is unrelated to firm size, so large and small firms have the same probabilities of achieving any particular growth rate in any period. Over time, some firms are 'lucky' and tend to enjoy an above-average share of high growth rates, while others are 'unlucky' and tend to remain the same size or decline. Concentration can be expected to increase naturally over time. Whatever

\footnotetext{
${ }^{2}$ Sutton (1997) presents an exhaustive survey on firm growth.
} 
the shape of the initial size distribution, over time the distribution will tend to become skewed.

There is extensive empirical evidence ${ }^{3}$ on the validity of the LPE for manufacturing in both the US and Europe. Results have been mixed. Most early studies found either no relationship or a positive relationship between size and growth (Hart and Prais 1956; Singh and Whittington 1975). Mansfield (1962) points out that there are three versions of Gibrat's Law. The first version postulates that the Law holds for firms that exited the industry as well as for those remaining in existence. The second interpretation is that the Law holds only for firms that survive over the relevant time period (Hart and Prais 1956). The third main version is that the Law applies only to firms that are large enough to exceed the minimum efficient scale (MES) ${ }^{4}$ level of output (Simon and Bonini 1958). Mansfield (1962) concludes that Gibrat's Law does not seem to hold up very well empirically. The discrepancy in conclusions about the validity of Gibrat's Law results from using three different types of samples of firms - all firms, only surviving firms, and only large surviving firms (i.e. surviving firms that operate at or above the MES level of output are included). According to Sutton (1997), Gibrat's Law holds under the third version but not under the first two.

More recently, studies have typically found that small firms grow faster, and tend to have more variable growth rates, than large firms (Wagner 1992; Dunne and Hughes 1994; Hart and Oulton 1996, 1999). Over time the models employed have become increasingly sophisticated. For example, some researchers have developed evolutionary learning models, in which younger and less experienced firms enjoy less stable growth than their older counterparts (Evans 1987a, b).

A rich body of empirical evidence, spanning numerous countries and time periods, has provided sufficient evidence for Geroski (1995), Sutton (1997), and Caves (1998) to infer stylized facts and stylized relationships about the basic elements concerning firm dynamics and industry evolution, or the manner in which firms enter an industry, grow or stagnate and ultimately survive or exit from the industry. The stylized facts emerging from the new literature have been sufficiently compelling to contradict what was previously classified as Gibrat's Law, which assumes that firm growth is independent on size, and to motivate Sutton (1997) to explain how this Law could be refuted when subjected to empirical scrutiny. Empirical evidence, including both small and large firms, suggests that the growth rates of surviving firms tend to fall systematically with increasing firm size. This finding emerged so consistently across different studies that Geroski (1995) classified it as a stylized result: "both firm size and age are correlated with the survival and growth of entrants". Sutton (1997) and Caves (1998) come to the same conclusion, thus leaving little support for the validity of Gibrat's Law. While Geroski (1995) considers the empirical evidence compelling enough to constitute a stylized result, Sutton (1997) only concludes that the proportional rate of growth of

\footnotetext{
3 See Audrestch et al. (2004) for a recent and exhaustive review of empirical studies on firm growth rates.

${ }^{4}$ MES is defined as the minimum size of the largest firms in a business group that accounts for one half of the value of sales in that business group.
} 
a firm, conditional upon survival, decreases with size. This ambiguity seems to arise from the type of firms included in the sample. Gibrat's Law tends to hold when only large firms or those that have exhausted scale economies are included in the sample (Geroski et al. 2003). Geroski (1995) finds the results interesting because they suggest that the growth patterns of large and small firms differ. As is well known, the growth rates of well-established corporations are random and do not seem to vary in any stable or systematic way with firm size. Although the importance of these facts for economic behaviour is manifest, their development has not been theory-driven and Gibrat's Law is still an empirical regularity in search of sound theoretical justification (Caves 1998).

Gibrat's Law of Proportional Effect is sufficiently general to not distinguish across specific types of economic activity. Surveys by Geroski (1995), Sutton (1997), and Caves (1998) imply that what holds for manufacturing would be expected to hold for the services sector. If this was not the case, the results based on manufacturing would actually represent a special case and application of Gibrat's Law. In testing Gibrat's Law for selected manufacturing and service industries in Taiwan, Chen and Lu (2003), applying panel unit root tests, have recently found that the Law can be rejected for the former but not for the latter industries. Audretsch et al. (2004) present theoretical reasons based on scale economies that may explain why Gibrat's Law would be expected to hold for the services sector but not for manufacturing.

Some authors have recently examined whether the Gibrat's Law of Proportionate Effect can be rejected for the services sector as it has been for manufacturing. The studies that deal exclusively with the services sector, namely the large scale services are: banking (Tschoegl 1983, 1996; Vander Vennet 2001; Goddard et al. 2004); credit unions (Goddard et al. 2002a, b); and insurance (Hardwick and Adams 2002). Only Piergiovanni et al. (2003) and Audretsch et al. (2004), deal with small scale services (hospitality sector).

The former group of studies conclude that growth is unrelated to initial size and that variability of growth decline with size. Growth in one period is not a good predictor of growth in subsequent periods. In this way, Gibrat's law is rejected. Finally, the studies that deal with small scale services obtained mixed results. Piergiovanni et al. (2003) and Audretsch et al. (2004) cannot conclude that the Law is generally valid, since the probability of a given proportionate change in size during the relevant period turns out to be the same for all firms only in relation to certain sub-sectors.

\section{Modelling firm growth dynamics}

Most previous empirical tests of Gibrat's Law are based on a cross-sectional regression of the logarithmic growth over some period on initial log size, and (optionally) lagged growth over a previous period (Chesher 1979). According to Goddard et al. (2002a, b), the cross-sectional procedure produces biased parameter estimates and the test suffers from a loss of power if there are heterogeneous individual firm effects. Suitably designed panel tests avoid these difficulties. 
Traditionally, empirical growth specifications have also been treated as static models. However, the dynamic nature of the panel model should be taken into account. For this reason, to analyse the validity of LPE and the empirical determinants of firm growth we take into consideration univariate and multivariate dynamic panel data models with fixed effects, estimated with the GMM-system estimator developed by Blundell and Bond (1998).

Univariate tests of the Law of Proportionate Effect (LPE) are based on a model in which logarithmic firm size and logarithmic growth (the first difference of log size) are the only variables. In this case, it is assumed that:

$$
\text { growth }_{i t}=\alpha_{i}+\delta_{t}+(\beta-1) \text { size }_{i t-1}+\mu_{i t} ; \quad \mu_{i t}=\rho \mu_{i t-1}+\varepsilon_{i t} .
$$

Equation 1 is a first order autoregressive model for size $e_{i t}$, the natural logarithm of the size of firm $i$ at time $t$. The values of the parameters in (1) determine the behaviour of log size over time. In particular, $\beta$ (describes the relationship between size and annual growth, and $\alpha_{i}$ and $\delta_{t}$ allow for individual and time effects, respectively. The unobserved time-invariant firm specific effects, $\alpha_{i}$, allows for heterogeneity across firms. $\rho$ (captures persistence of chance or serial correlation in $\mu_{i t}$, the disturbance term of the growth equation. Finally, $\varepsilon_{i t}$, is a random disturbance, assumed to be normal, independent and identically distributed (IID) with $E\left(\varepsilon_{i t}\right)=0$ and $\operatorname{var}\left(\varepsilon_{i t}\right)=\sigma_{\varepsilon}^{2}>0$. Tschoegl (1983) identifies three testable propositions which derive from the LPE: first, growth rates are independent of firm size; second, above or below average growth for any individual firm does not tend to persist from one period to the next; and third, the variability of growth is independent of firm size.

The analysis of the relationship between growth and size consists of testing the null hypothesis $\left(H_{0}: \beta-1=0\right)$ embodied in the LPE which states that the probability distribution of growth rates is the same for all classes of firm. If $\beta \geq 1$ in (1), $\alpha_{i}=0$ for all $i .^{5} \beta>1$ implies company growth trajectories that are explosive: firms tend to grow faster as they get larger. Such a pattern is conceivable for a limited time, but presumably could not continue indefinitely. The variance of the cross-sectional firm size distribution and the level of concentration both increase over time. $\beta=1$ implies non-explosive growth, which is unrelated to firm size. In this situation the LPE holds, which means that the mean and variance of growth is independent of size. Again, the variance of the firm size distribution and the level of concentration increase over time. If $\beta<1$ firm sizes are mean-reverting. ${ }^{6}$ In this case the interpretation of $\alpha_{i}$ is different: $\alpha_{i} /(1-\beta)$ is the average log size to which firm $i$ tends to revert in the long term. It is therefore necessary to assume $\alpha_{i}>0$. Cross-sectionally, $\alpha_{i}$ can be considered as being IID with $E\left(\alpha_{i}\right)=0$ and $\operatorname{var}\left(\alpha_{i}\right)=$ $\sigma_{\alpha}^{2} \geq 0$. If $\sigma_{\alpha}^{2}=0$ the individual effects are homogeneous (all firms tend to revert towards the same mean size) and if $\sigma_{\alpha}^{2} \geq 0$ they are heterogeneous (the mean sizes are firm-specific). Thus, departures from Gibrat's Law arise: if $\beta \neq 1$, firm sizes

\footnotetext{
${ }^{5} \alpha \neq 0$ would allow for a deterministic trend specific to each firm, which could exist but which would be very difficult to identify with few observations per firm. The possibility of a common deterministic trend is captured, however, through the time effects $\delta_{t}$.

${ }^{6}$ With $\beta<1$, in the short run it is possible for the variance of the cross-sectional distribution of firm sizes to either increase or decrease. In the long run, however, this variance converges and stabilises at its equilibrium value.
} 
regress towards or away from the mean size; if $\rho>0$ then above average growth in one period tends to persist into the next, or if $\rho<0$ then a period of above average growth tends to be followed by one of below average growth; or if $\sigma_{\varepsilon}^{2}=\sigma_{\varepsilon}^{2}(i, t)$ then growth rates are heteroskedastic.

The results of LPE tests have been mixed, with several early studies either finding no relationship or a positive relationship between size and growth. Earlier studies found that Gibrat's Law holds, at least as a first approximation, but most of them are based on samples of the largest firms in the economy, or quoted firms. Others, including more recent studies, identify an inverse relationship and therefore reject the LPE (Hall 1987; Evans 1987a, b; Dunne and Hughes 1994; Hart and Oulton 1996; Goddard et al. 2002a, b).

Following Goddard et al. (2002a, b), and for the purposes of panel estimation, (1) can be re-written as follows:

$$
\text { growth }_{i t}=\alpha_{i}(1-\rho)+\delta_{t}+(\beta-1) \text { size }_{i t}+\rho \text { growth }_{i t-1}+\eta_{i t}
$$

where $\eta_{i t}=\varepsilon_{i t}+\rho(1-\beta)$ size $_{i t-2}$, so $\eta_{i t}=\varepsilon_{i t}$ under $H_{0}: \beta=1$.

One remarkable fact about the model (2) is its lack of economics. This idea is confirmed by most of recent empirical literature that has rejected the law and suggested that firm growth may be explained by others variables. Recent contributions to the explanation of firm growth include the role of Foreign Direct Investment (FDI) (Bellak 2004; Pfaffermayr and Bellak 2000), and financial structure (Becchetti and Trovato 2002; Fotopoulos and Louri 2004; Ushijima 2005). Thus, to study the empirical determinants of firm growth we consider the multivariate model that is based on expanded version of (2), and that incorporates additional independent variables on the right hand side:

$$
\begin{aligned}
\text { growth }_{i t}= & \alpha_{i}(1-\rho)+\delta_{t}+(\beta-1) \text { size }_{i t-1}+\text { sgrowt }_{i t-1} \\
& +\sum_{j=1}^{k} \gamma_{j} x_{j i t-1}+\pi \text { fown }_{s t}+\eta_{i t}
\end{aligned}
$$

where $x_{j i t-1}$, contains a set of explanatory variables, such as the natural logarithmic of firm age and natural logarithmic of financial structure (leverage and liquidity ratios), and fown $_{s t}$, is a natural logarithmic percentage of foreign participation in industry $s$ (NACE-three digits) in period $t$. In this case, we test the null hypotheses of $H_{0}: \gamma_{j}=0$ and $H_{0}: \pi=0$, against the alternative that they are different from zero. If we do not reject these null hypotheses this means that firm age, foreign participation and financial structure have no influence on the growth of the firms.

Equations 2 and 3 permit direct tests of the first two of Tschoegl's (1983) three testable propositions: that growth rates are independent of firm size $(\beta-1=0)$, and that growth does not persist $(\rho=0)$. The third proposition that the variability of growth is independent of size can be investigated by applying a standard heteroskedasticity test to the residuals of each estimated equation.

Jovanovic (1982) developed a theoretical model that could account for possible departures from Gibrat's Law. His model of "noisy" selection predicts a negative relationship between the size and age of firms and their growth that must be linked 
to their learning capacity. The life cycle pattern of the firm determines how much it will be able to grow. The model assumes that firms are heterogeneous with respect to their true efficiencies and, consequently, cost levels. Firms learn about their true efficiencies as they operate in an industry. In a Bayesian learning process, experience enables firms to update their expectations regarding the value of their efficiency. Jovanovic's model includes a selection mechanism. Those that make positive discoveries about their true efficiencies survive and grow, whereas the others decline and exit. With firm size and age, failure and growth rates decrease. An old, large operating firm is, in all probability, one that has made a series of positive discoveries about its true efficiency, leaving less scope for further efficiency gains from learning. This model has motivated the inclusion of firm age along with initial size in empirical models dealing with firm growth.

A negative age growth relation, as predicted by Jovanovic's (1982) model, has been revealed in a number of empirical studies and different country contexts (Evans 1987b; Dunne et al. 1989; Variyam and Kraybill 1992 for US; Dunne and Hughes 1994 for UK; Kamshad 1994 for France; Farinas and Moreno 2000 for Spain; Becchetti and Trovato 2002 for Italy; and Nurmi 2003 for Finland). By sorting the firms into intervals related to their age, Evans (1987a, b) showed that firm age is an important factor in explaining firm growth. Firm growth seems to decrease with age. Similar results were given by Dunne and Hughes (1994). They conclude that young firms grew more rapidly when analysing a specific size class of firms. Exceptions are provided by Das (1995) who studied firm growth in the computer hardware industry in India, and Elston (2002). Both studies found a positive effect of firm age on firm growth. In Heshmati (2001) the negative relationship between age and growth of Swedish firms holds for growth measured in employment terms, while it is positive in asset and sales firm growth models.

Researchers have only recently started to investigate the potential effects of FDI on firm growth. Markusen and Venables (1999) put forward a formal analysis of how linkages between foreign and domestic supplier firms may work as a catalyst for industrial development. The initial positive effects of increased (foreign) demand on the supplier (intermediate goods producing) firms are to increase their profits, thereby attracting more investment in the sector, which leads to lower intermediate goods prices, so favouring customer (final goods producing) firms. Such (demand) spillovers may cause a subsequent increase in investment, which may be expressed either in new entry or in the higher growth of existing firms. Görg and Strobl (2001) test the Markusen and Venables (1999) model using Irish data on firm entry and confirm its findings, estimating a strong positive effect of multinational firms on both net and gross entry.

Examining performance gaps between foreign-owned and domestic-owned Austrian firms, Pfaffermayr and Bellak (2000) consider, among other gaps, the effect of foreign ownership on firm growth in terms of employment, sales and productivity. Firms were classified as foreign owned if the owner of a majority share is based in a foreign country, and firms employing less than 10 employees were excluded from the sample. The results obtained find no impact of foreign ownership on firm growth. Initial size in terms of employment was found to have a negative effect on firm employment growth. In a recent paper, Oulton (2001) finds that 
foreign ownership had a positive effect on firm capital-stock growth in the UK from 1975 to 1979 and 1981 to 1989.

Blonigen and Tomlin (2001) studied the relationship between size and growth in the context of foreign-owned firms, in particular Japanese plants in the US. In particular, they search for evidence on Gibrat's Law and ask whether size and growth of foreign-owned affiliates is similar to that found for domestic plants. Since firm growth is also related to firm age they control for age. The authors indicate that testing for learning effects proves significant to foreign-owned firms. Foreignowned plants may face all the challenges domestic plants face, but additional uncertainties, related to operating in foreign markets, arise for foreign-owned plants, such as obtaining material inputs, etc. They argue for slower growth rates of foreign-owned firms in the case of first entry into a market, because of uncertainties in foreign markets like inefficiencies or problems in obtaining material inputs. Inefficiencies may arise from monitoring workers' problems or other factors. Another factor behind the slower growth of foreign firms could be their lower capital intensity, if, for example, they start as small plants. On the other hand, there are also powerful arguments for foreign firms enjoying higher growth rates. Because growth is related to learning, the type of FDI becomes potentially important: It is hypothesised that it makes a difference whether an investing firm acquires a certain stock of know-how instantaneously (acquisition) and has to adapt it, or whether this has to be built up from scratch (greenfield), not reaping the benefits of pathdependence. Their results suggest that smaller and younger Japanese plants in US grow faster, so their estimates strongly reject Gibrat's Law. Their findings also reveal substantial learning effects and effects of earlier investments on the likelihood of future investments.

Ushijima (2005) reaffirms that smaller and younger Japanese affiliates in the US grow faster than their larger and older counterparts. The previous experience of the parent Japanese company in the US has a negative effect on growth and a positive one on the survival of Japanese affiliates in the US. These effects are statistically insignificant, suggesting that a parent company's prior experience in the foreign market is only a limited substitute for a plant's own learning. Fotopoulos and Louri (2004), applying Quantile regression techniques to a cross-section of 2,640 manufacturing firms operating in Greece in the 1992-1997 period, highlight the role of foreign participation in increasing firm growth with varying intensity depending on the industry group and the Quantile regression. Lastly, Bellak (2004) surveyed performance differences between domestic and foreign firms. In particular, this author examined whether larger foreign firms grow faster than larger domestic firms. Gibrat's Law is certainty worth considering, since firm size has been established as an explanatory factor with respect to several gaps. The theoretical argument is based on the idea that foreign firms enjoy an advantage over their domestic counterparts in the host country, which is "supplied" by their parent company at low cost.

Finally, in another strand of the literature, attempts have been made to account for differences in corporate growth across firms by drawing on the possible effects of firms' financial structure. The theoretical nexus runs from financial structure, through its effects on a firm's investment decisions, and finally to its effect on firm 
size and growth dynamics. A central issue is whether leverage affects a firm's investment decision and ultimately its growth, given its investment opportunities. ${ }^{7}$ It seems that opinion is divided about the effect of leverage on investment policies. On the one hand a firm with good investment projects is assumed to be able to raise funds whatever its debt exposure is, and on the other it is argued that a large debt overhang may prevent a firm from financing positive net present value projects with external funds (Lang et al. 1996). Cooley and Quadrini (2001) develop a theoretical model that introduces financial market frictions and persistent shocks into a learning framework of firm dynamics and produces results consistent with the empirical regularities of the negative effects of initial firm size and of firm age on firm growth.

Empirical evidence for the effects of financial conditions on firm growth has been rather limited. Lang et al. (1996) examine the relation between leverage and growth over a 20-year period using a sample of large US industrial firms. The significantly negative coefficient estimated places additional weight on the effect of leverage on firm growth, as this would be expected to be weaker for the large firms used in the analysis having access to stock markets. It is further clarified that the strong negative effect holds for firms known to have low growth opportunities (low Tobin's q), but not significantly so for firms with good growth prospects (high q). Low leverage might be signalling management's private information about a firm's future growth prospects. Thus, in a firm with low investment opportunities, a large debt may prevent management from undertaking poor projects. So a negative relation between leverage and firm growth might be discerned. Heshmati (2001) finds that indebtedness affects the growth rate of firms negatively in terms of assets, but affects the growth rates of firms positively in terms of sales, while it has no effect on firm growth defined in employment terms. In Beccetti and Trovato's (2002) study, leverage negatively determines the growth of firms with less 50 employees. Lastly, Ushijima (2005) examines, among other factors, the effects of financial conditions of Japanese parent companies on the growth and survival of their US affiliates. Plants belonging to parent companies with greater liquidity were found to grow faster and be likely to disappear. On the other hand plants belonging to parent firms that are highly leveraged grow more slowly and are less likely to survive.

\section{Methodology}

This section aims to describe the econometric methodology that we could use to estimate the dynamic panel models (2) and (3): pooled OLS, within and GMM estimators. If the homogeneity assumption $\left(\sigma_{\alpha}^{2}=0\right.$ or $\left.\alpha_{i}=\alpha\right)$ is valid under $H_{1}$ : $\beta<1, \alpha_{i}(1-\rho)$ in (2) can be replaced by $\alpha(1-\rho)$, and we can estimate by pooling the data across firms and over time, and by using OLS with time dummies to allow for the (fixed) time effects, $\left(\delta_{t}-\rho \delta_{t-1}\right)$. The pooled OLS estimator is inconsistent, since the explanatory variable, size $e_{i t-1}$, is positively correlated with the error term due to the presence of firm-specific effects. Wiping out the fixed effects does not

\footnotetext{
${ }^{7}$ Much discussion on these issues can be found in Lang et al. (1996), and a thorough review of theories of capital structure in Harris and Raviv (1991).
} 
solve the endogeneity problem because the lagged dependent variable, size $e_{i t-1}$, is still correlated with the error term.

Alternatively, (2) could be estimated using the within estimator, which is equivalent to estimation by OLS including (as well as the time dummies) a full set of cross-sectional dummies to allow for the possibly heterogeneous individual firm effects, $\alpha_{i}$. However, it is generally known that the within estimator generates inconsistent estimates in dynamic specifications. Since the OLS estimator is biased upwards, and the within estimator is biased downwards, the consistent estimator should lie between the OLS and within estimates. ${ }^{8}$ The bias diminishes only when the number of time periods approaches infinity despite the large number of crosssectional observations.

As a consequence, further analysis with the generalized method of moments (GMM), in particular the GMM-system estimator, is needed. This estimator controls for the presence of unobserved firm-specific effects and for the endogeneity of the current-dated explanatory variables. The GMM-system estimator uses equations in first-differences, from which the firm-specific effects are eliminated by the transformation, and for which endogenous lagged variables for two or more periods will be valid instruments, provided there is no serial correlation in the timevarying component of the error terms. This is tested by examining tests for serial correlation in the first-differenced residuals (see Arellano and Bond 1991). These differenced equations are combined with equations in levels, for which the instruments used must be orthogonal to the firm-specific effects. Obviously the level of the dependent variable must be correlated with the firm-specific effects, and we want to allow for the levels of all the explanatory variables to be potentially correlated with the firm-specific effects, so this rules out using the levels of any variables as instruments for the levels equations. However, Blundell and Bond (1998) show that in autoregressive-distributed lag models, the first-differences of the series can be uncorrelated with the firm-specific effects provided that the series have stationary means. We therefore experimented with lagged differences of the variables as instruments for the levels equations. The instruments used depend on the assumption made as to whether the variables are endogenous, predetermined or exogenous. The precise instruments that we used are indicated in the tables. Instrument validity was tested using a Sargan test of over-identifying restrictions.

\section{Data and descriptive statistics}

The data set used in this paper was drawn from several sources. Most of the individual firm's information was collected by the Bank of Portugal, which each year studies a random sample of services firms from the underlying population. The firms are classified according to the sector of their main activity (NACE, five digit classification). According to the statistical classification of economic activities in the European Community (NACE), our services sector sample includes firms from the real estate, renting and business spheres. Following a two digit classification, the

\footnotetext{
$\overline{8}$ According to standard results this holds, at least in large samples, without other explanatory variables.
} 
services sector includes firms from: Real estate activities (70); Renting of machinery and equipment without operator and of personal and household goods (71); Computer and related activities (72); and Other business activities (74). This data source provides financial data mostly based on the firms' accounts but lacks information on their ownership structure. To include such information in our data set, we had to combine the Bank of Portugal data with other sources. In particular, data on foreign ownership has been derived from Quadros de Pessoal, a data set produced by the Portuguese Ministry of Labour and based on a standardized questionnaire that all firms with wage earners must answer every year.

For the purpose of this paper, cleaning procedures have been followed. Firstly, we removed from the original sample firms whose industry activity was unknown. Secondly, we excluded observations with either missing or non-positive values for the variables used (number of employees, age, foreign participation, leverage and liquidity ratios). The introduction of this restriction was unavoidable. Thirdly, for the empirical part of this paper the data is limited to surviving firms because it is not possible to analyse the persistence of growth for firms that leave the industry during the observation period. Due to the higher probability of slowly-growing small firms exiting, sample selection issues may be a problem when the data sample consists only of surviving firms. However, because of the short growth interval used, it is believed that the sample selection bias is not likely to be very large for the data set used. Finally, given the requirements of the adopted econometric methodology we selected only firms with at least four consecutive periods.

The final sample is an unbalanced panel that includes 419 surviving services firms in Portugal in the period from 1995 to 2001, with a number of contiguous observations ranging from 4 to 7 for a total of 1,923 observations. Just recently it has become obligatory for the services firms to be included in the sample, which explains the reduced number. Due to the higher probability of slowly-growing small firms exiting, sample selection issues may be a problem when the data sample consists only of surviving firms. Thus, due to the short growth interval used, it is believed that the sample selection bias is not likely to be very large for the data set used. Furthermore, most of the earlier studies (Evans 1987; Hall 1987; Mata 1994; Dunne and Hughes 1994; Heshmati 2001; Nurmi 2003) have concluded that the negative relationship between firm size and growth is not due to sample selection bias alone. So it may be more beneficial to concentrate solely on the dynamic panel data model's context and leave the selection issue aside.

The dependent variable, GROWTH, is measured by the employment growth rate in two consecutive years. Employment is chosen as a unit of analysis in order to allow for comparisons with various earlier studies, to avoid the effects of inflation and to draw policy conclusions from the employment perspective. The choice of explanatory variables is theoretically driven and aims to proxy firm and industry-specific characteristics that are likely to determine the growth of the firms. With reference to firm-specific characteristics, we measure firm size (SIZE) by the number of employees, and firm age (AGE) by the number of years a firm is operating in an industry. In order to proxy financial risk we define the covariate LEV as the ratio of book values of total liabilities to total assets and the covariate LIQ as the ratio of current assets minus inventories to total assets. Concerning to industry-specific 
Table 1 Descriptive statistics

\begin{tabular}{lccccc}
\hline & Mean & St. Dv. & 1st Q. & Median & 3rd Q. \\
\hline GROWTH & -0.018 & 0.280 & -0.095 & 0 & 0.0513 \\
SIZE & 38 & 57 & 7 & 17 & 40 \\
AGE & 17.41 & 14.92 & 8 & 13.5 & 22 \\
Fown & 12.38 & 11.46 & 3 & 9.3 & 18.8 \\
LEV & 79.59 & 24.61 & 67.8 & 79.7 & 88.92 \\
LIQ & 36.26 & 22.08 & 19.87 & 33.07 & 50.39 \\
\hline
\end{tabular}

characteristics, the share of foreign capital, FOWN, is the percentage of equity capital held by foreign investors in sector $s$. This variable measures the spillover effect and is computed at the three-digit industry level. All variables have been subjected to logarithmic transformation (natural $\log$ ) and are expressed with small caps.

A statistical summary of the variables used in the regression analysis is reported in Table 1. The average number of employees is about 38 , whereas the median, a measure that is less susceptible to outliers, is 17 employees. The median and percentile 75 confirm the findings of other studies, which fall within the usual definition of a small and medium sized business adopted by the European Union. It is known that large numbers of jobs are created in small and medium-sized firms (SMEs), it should also be recognized that many jobs are lost by the closure of smaller firms (Davis et al. 1996; Caves 1998). On average the firm is 17 years old, whereas the median is 14 years old, which means that most of the firms are small and young. The average share of foreign ownership in our sample is $12.38 \%$. In relation to financial variables most of the firms exhibit high leverage and liquidity ratios.

Before we ran any estimation we calculated the correlation matrix among the variables used in this study. Some of the correlation coefficients are above 0.10: the positive ones fall between size and age, size and share of foreign participation and the negative ones between leverage and liquidity. The high correlation between size and age (0.3986) may be explained because firm size could be used as a proxy for the age of firms, in the sense that firms who start their business are usually small. These results will be made available upon request.

\section{Results and interpretations}

This section presents and interprets the estimation results for the univariate and multivariate firm growth equations with serial correlation estimated by GMMsystem. The system GMM estimates that we report are computed using DPD for OX (Doornik et al. 2002). We report results for a one-step GMM estimator, with standard errors that are asymptotically robust to general heteroskedasticity ${ }^{9}$, only the Sargan test comes from the second-step. The estimation results with models (2) and (3) for whole sample are reported in Table 2, whilst Tables 3 and 4 report the

\footnotetext{
9 Although a more efficient two-step GMM estimator is available, the asymptotic standard errors for the two-step estimator can be an unreliable guide for inference in finite samples. Thus, inference based on the one-step estimator has been found to be more reliable than the one based on the (asymptotically) more efficient two-step estimator (Arellano and Bond 1991).
} 
Table 2 GMM-SYS results for whole sample

\begin{tabular}{|c|c|c|c|c|c|}
\hline \multicolumn{2}{|r|}{ [1] } & {$[2]$} & [3] & [4] & [5] \\
\hline Const & $\begin{array}{l}0.0789 * * * \\
(0.026)\end{array}$ & $\begin{array}{l}0.1509 * * * \\
(0.0435)\end{array}$ & $\begin{array}{l}0.1526 * * * \\
(0.0484)\end{array}$ & $\begin{array}{c}0.0131 \\
(0.3825)\end{array}$ & $\begin{array}{c}0.0104 \\
(0.3561)\end{array}$ \\
\hline $\operatorname{size}_{\mathrm{it}-1}$ & $\begin{array}{c}-0.0311 * * * \\
(0.0064)\end{array}$ & $\begin{array}{l}-0.0206^{* * * *} \\
(0.008)\end{array}$ & $\begin{array}{c}-0.0255^{* * *} * \\
(0.0092)\end{array}$ & $\begin{array}{c}-0.0268 * * * \\
(0.0098)\end{array}$ & $\begin{array}{c}-0.0267 * * * \\
(0.0097)\end{array}$ \\
\hline growth $_{\mathrm{it}-1}$ & $\begin{array}{c}-0.1239 \\
(0.2306)\end{array}$ & $\begin{array}{r}-0.1633 \\
(0.1739)\end{array}$ & $\begin{array}{c}-0.3906 * * \\
(0.1724)\end{array}$ & $\begin{array}{c}-0.4147 * * \\
(0.2067)\end{array}$ & $\begin{array}{c}-0.3642 * * \\
(0.1719)\end{array}$ \\
\hline$a g e_{\mathrm{it}-1}$ & - & $\begin{array}{c}-0.0417 * * \\
(0.019)\end{array}$ & $\begin{array}{c}-0.0452 * * \\
(0.0205)\end{array}$ & $\begin{array}{c}-0.0421^{*} \\
(0.0222)\end{array}$ & $\begin{array}{c}-0.0389^{*} \\
(0.0208)\end{array}$ \\
\hline fown $n_{\mathrm{it}-1}$ & - & - & $\begin{array}{c}0.0102 \\
(0.0104)\end{array}$ & $\begin{array}{c}0.0103 \\
(0.0101)\end{array}$ & $\begin{array}{l}0.0103 \\
(0.01)\end{array}$ \\
\hline$l e v_{\mathrm{it}-1}$ & - & - & - & $\begin{array}{c}0.0314 \\
(0.0866)\end{array}$ & $\begin{array}{c}0.0414 \\
(0.0844)\end{array}$ \\
\hline$l i q_{\mathrm{it}-1}$ & - & - & - & - & $\begin{array}{r}-0.0147 \\
(0.0261)\end{array}$ \\
\hline $\mathrm{W}_{\mathrm{JS}}$ & \multirow{2}{*}{$\begin{array}{c}23.80[0.000] \\
(25) 26.05 \\
{[0.405]}\end{array}$} & $27.02[0.000]$ & $28.95[0.000]$ & $25.39[0.000]$ & $28.51[0.000]$ \\
\hline Sargan & & $\begin{array}{l}\text { (43) } 34.74 \\
{[0.811]}\end{array}$ & $\begin{aligned} & 58.99 \\
& {[0.549] }\end{aligned}$ & $\begin{array}{l}\text { (79) } 85.27 \\
{[0.295]}\end{array}$ & $\begin{aligned} & 98.59 \\
& {[0.436] }\end{aligned}$ \\
\hline$m_{1}$ & -1.914 [0.056] & $-2.193[0.028]$ & $-1.685[0.092]$ & $-1.454[0.146]$ & -1.818 [0.069] \\
\hline$m_{2}$ & $-0.6556[0.512]$ & 2] -1.029 [0.303] & $-1.963[0.050]$ & $-1.828[0.067]$ & $-1.842[0.066]$ \\
\hline Instrument & size $(3,4)$ & size $(3,4)$ & size $(3,4)$ & size $(3,4)$ & size $(3,4)$ \\
\hline matrix & $\Delta$ size $(2,2)$ & age $(2,2)$ & age $(2,2)$ & age $(2,2)$ & age $(2,2)$ \\
\hline & & $\Delta$ size $(2,2)$ & fown $(2,2)$ & fown $(2,2)$ & fown $(2,2)$ \\
\hline & & $\Delta a g e(1,1)$ & $\Delta$ size $(2,2)$ & $\operatorname{lev}(2,2)$ & $\operatorname{lev}(2,2)$ \\
\hline & & & Dage $(1,1)$ & $\Delta$ size $(2,2)$ & $\operatorname{liq}(2,2)$ \\
\hline & & & $\Delta$ fown $(1,1)$ & Dage $(1,1)$ & $\Delta$ size $(2,2)$ \\
\hline & & & & $\Delta$ fown $(1,1)$ & Dage $(1,1)$ \\
\hline & & & & $\Delta l e v(1,1)$ & $\Delta$ fown $(1,1)$ \\
\hline & & & & & $\Delta l e v(1,1)$ \\
\hline & & & & & $\Delta \operatorname{liq}(1,1)$ \\
\hline
\end{tabular}

Notes: All estimates include a full set of time dummies as regressors and instruments. The null hypothesis that each coefficient is equal to zero is tested using one-step robust standard errors. Asymptotic standard errors robust to general cross-section and time-series heteroskedasticity are reported in parenthesis. $\mathrm{W}_{\mathrm{JS}}$ is the Wald statistic of joint significance of the independent variables (excluding time dummies and the constant term). Sargan is a test of the validity of the overidentyfing restrictions based on the efficient twostep GMM estimator. $m_{1}\left(m_{2}\right)$ is a test of the null hypothesis of no first- (second-) order serial correlation. $p$-values in square brackets and degrees of freedom in round brackets. The underlying sample consists of 419 firms and a total of 1,923 observations

$*, * *, * * *$ Significant at $10 \%, 5 \%$ and $1 \%$ respectively

results when we split sample by size. Following the usual definition of micro, small and larger firms adopted by the European Union our sample of smallest firms includes those with less than 50 employees, whereas the sample of larger firms includes those with 250 employees or more. ${ }^{10}$

\footnotetext{
${ }^{10}$ Because pooled OLS is not an appropriate estimator of the parameters of the growth specifications, we focused on GMM-system results. The pooled OLS results will be made available upon request.
} 
Table 3 GMM-sys results for micro and small firms ( $<50$ employees)

\begin{tabular}{|c|c|c|c|c|c|}
\hline & {$[1]$} & {$[2]$} & [3] & [4] & [5] \\
\hline const & $\begin{array}{l}0.0836 * \\
(0.0446)\end{array}$ & $\begin{array}{l}0.1789 * * \\
(0.0691)\end{array}$ & $\begin{array}{l}0.1878 * * * \\
(0.0606)\end{array}$ & $\begin{array}{l}-0.213 \\
(0.5897)\end{array}$ & $\begin{array}{r}-0.3442 \\
(0.5548)\end{array}$ \\
\hline $\operatorname{size}_{\mathrm{it}-1}$ & $\begin{array}{c}-0.0329 * * \\
(0.0135)\end{array}$ & $\begin{array}{c}-0.0233^{*} \\
(0.0124)\end{array}$ & $\begin{array}{c}-0.0276^{* * *} \\
(0.0135)\end{array}$ & $\begin{array}{c}-0.0293 * * \\
(0.0136)\end{array}$ & $\begin{array}{c}-0.03 * * \\
(0.0136)\end{array}$ \\
\hline growth $_{\mathrm{it}-1}$ & $\begin{array}{c}-0.2758 \\
(0.3377)\end{array}$ & $\begin{array}{r}-0.3475 \\
(0.2588)\end{array}$ & $\begin{array}{c}-0.5155^{* *} \\
(0.2011)\end{array}$ & $\begin{array}{l}-0.4785^{* * * *} \\
(0.1327)\end{array}$ & $\begin{array}{c}-0.445^{* * *} \\
(0.1179)\end{array}$ \\
\hline$a g e_{\mathrm{it}-1}$ & - & $\begin{array}{r}-0.051^{*} \\
(0.0265)\end{array}$ & $\begin{array}{c}-0.0524^{* *} \\
(0.0253)\end{array}$ & $\begin{array}{c}-0.0426^{*} \\
(0.0223)\end{array}$ & $\begin{array}{c}-0.0408 * \\
(0.0217)\end{array}$ \\
\hline fown $_{\mathrm{it}-1}$ & - & - & $\begin{array}{c}0.0034 \\
(0.0115)\end{array}$ & $\begin{array}{c}0.0042 \\
(0.012)\end{array}$ & $\begin{array}{c}0.0044 \\
(0.012)\end{array}$ \\
\hline$l e v_{\mathrm{it}-1}$ & - & - & - & $\begin{array}{c}0.0874 \\
(0.1369)\end{array}$ & $\begin{array}{c}0.1106 \\
(0.1274)\end{array}$ \\
\hline$l i q_{\mathrm{it}-1}$ & - & - & - & - & $\begin{array}{l}0.008 \\
(0.0239)\end{array}$ \\
\hline $\mathrm{W}_{\mathrm{JS}}$ & 6.486 [0.039] & $10.56[0.014]$ & $15.18[0.004]$ & $24.01[0.000]$ & $28.40[0.000]$ \\
\hline Sargan & $\begin{array}{l}\text { (17) } 14.67 \\
{[0.619]}\end{array}$ & $\begin{array}{l}\text { (35) } 26.05 \\
{[0.863]}\end{array}$ & $\begin{array}{l}47.03 \\
{[0.704]}\end{array}$ & $\begin{array}{l}\text { (71) } 69.37 \\
{[0.533]}\end{array}$ & $\begin{array}{l}\text { (89) } 80.84 \\
{[0.719]}\end{array}$ \\
\hline$m_{1}$ & $-1.217[0.224]$ & $-1.384[0.166]$ & $-1.358[0.175]$ & $-1.814[0.070]$ & $-2.027[0.043]$ \\
\hline$m_{2}$ & $-0.914[0.361]$ & $-1.415[0.157]$ & $-1.774[0.076]$ & $-1.845[0.065]$ & $-1.839[0.066]$ \\
\hline \multirow{10}{*}{$\begin{array}{l}\text { Instrument } \\
\text { matrix }\end{array}$} & size $(3,3)$ & size $(3,3)$ & size $(3,3)$ & size $(3,3)$ & size $(3,3)$ \\
\hline & $\Delta$ size $(2,2)$ & age $(2,2)$ & age $(2,2)$ & age $(2,2)$ & age $(2,2)$ \\
\hline & & $\Delta$ size $(2,2)$ & fown $(2,2)$ & fown $(2,2)$ & fown $(2,2)$ \\
\hline & & Dage $(1,1)$ & $\Delta$ size $(2,2)$ & $\operatorname{lev}(2,2)$ & $\operatorname{lev}(2,2)$ \\
\hline & & & Dage $(1,1)$ & $\Delta$ size $(2,2)$ & $\operatorname{liq}(2,2)$ \\
\hline & & & $\Delta$ fown $(1,1)$ & $\Delta a g e(1,1)$ & $\Delta$ size $(2,2)$ \\
\hline & & & & $\Delta$ fown $(1,1)$ & Dage $(1,1)$ \\
\hline & & & & $\Delta l e v(1,1)$ & $\Delta$ fown $(1,1)$ \\
\hline & & & & & $\Delta l e v(1,1)$ \\
\hline & & & & & $\Delta l i q(1,1)$ \\
\hline
\end{tabular}

Notes: As in Table 2. The underlying sample consists of 319 firms and a total of 1,459 observations $*, * *, * * *$ Significant at $10 \%, 5 \%$ and $1 \%$ respectively

Column [1], in Tables 2-4, gives Gibrat's original specification estimating the impact of initial firm size or past growth on growth (Gibrat 1931), i.e., model (2). In this column, we have ignored any other non-stochastic determinants of firm growth and concentrated on the relationship between size and growth. The GMM results for the whole sample, Table 2, show that the estimated coefficient of size is always negative and significant at $1 \%$ significance level, indicating that small firms are growing faster than larger ones during the period. Thus, we find that firm growth always decreases with firm size, which is inconsistent with theories that assume or imply Gibrat's Law. Since one of the size measures used is employment it follows that smaller firms generated more jobs, in proportion to their size, than did the larger firms. One possible explanation, in economic terms, is that there is a minimum efficient scale of the firm and until this size is reached, the firm experiences falling average costs and 
Table 4 GMM-sys results for large firms ( $\geq 250$ employees)

\begin{tabular}{|c|c|c|c|c|c|}
\hline & [1] & [2] & [3] & [4] & [5] \\
\hline const & $\begin{array}{c}-1.6439^{* *} \\
(0.7231)\end{array}$ & $\begin{array}{c}-0.9126^{* *} \\
(0.4493)\end{array}$ & $\begin{array}{l}-0.8103 * * * \\
(0.271)\end{array}$ & $\begin{array}{c}-0.647 \\
(0.4223)\end{array}$ & $\begin{array}{c}-0.6522 \\
(0.4157)\end{array}$ \\
\hline $\operatorname{size}_{\mathrm{it}-1}$ & $\begin{array}{c}0.2336^{* *} \\
(0.1065)\end{array}$ & $\begin{array}{c}0.1389^{* * *} \\
(0.0646)\end{array}$ & $\begin{array}{l}0.149 * * * \\
(0.0255)\end{array}$ & $\begin{array}{l}0.1314 * * * \\
(0.0273)\end{array}$ & $\begin{array}{l}0.1117 * * * \\
(0.0231)\end{array}$ \\
\hline growth $_{\mathrm{it}-1}$ & $\begin{array}{c}-0.2756 \\
(0.1689)\end{array}$ & $\begin{array}{c}-0.2254^{* * *} \\
(0.1108)\end{array}$ & $\begin{array}{c}-0.1967^{* * *} \\
(0.0815)\end{array}$ & $\begin{array}{c}-0.1752^{*} \\
(0.1018)\end{array}$ & $\begin{array}{c}-0.1347 \\
(0.0978)\end{array}$ \\
\hline$a g e_{\mathrm{it}-1}$ & - & $\begin{array}{c}-0.0263 \\
(0.0168)\end{array}$ & $\begin{array}{c}-0.0388^{*} \\
(0.0196)\end{array}$ & $\begin{array}{c}-0.0391^{*} \\
(0.0209)\end{array}$ & $\begin{array}{c}-0.0316 \\
(0.0287)\end{array}$ \\
\hline fown $_{\mathrm{it}-1}$ & - & - & $\begin{array}{r}-0.0448^{*} \\
(0.0242)\end{array}$ & $\begin{array}{c}-0.0469^{* * *} \\
(0.0224)\end{array}$ & $\begin{array}{c}-0.0442^{* *} \\
(0.0211)\end{array}$ \\
\hline$l e v_{\mathrm{it}-1}$ & - & - & - & $\begin{array}{r}-0.0086 \\
(0.0913)\end{array}$ & $\begin{array}{c}0.0234 \\
(0.0996)\end{array}$ \\
\hline$l i q_{\mathrm{it}-1}$ & - & - & - & - & $\begin{array}{r}-0.0104 \\
(0.0664)\end{array}$ \\
\hline $\mathrm{W}_{\text {JS }}$ & $5.001[0.082]$ & $9.137[0.028]$ & $102.0[0.000]$ & $86.72[0.000]$ & $77.20[0.000]$ \\
\hline Sargan & $\begin{array}{r}\text { (17) } 4.846 \\
{[0.998]}\end{array}$ & $\begin{array}{l}\text { (37) } 5.646 \\
{[1.000]}\end{array}$ & $\begin{array}{c}\text { (57) } 5.782 \\
{[1.000]}\end{array}$ & $\begin{array}{r}(77) 6.336 \\
{[1.000]}\end{array}$ & $\begin{array}{r}\text { (97) } 3.683 \\
{[1.000]}\end{array}$ \\
\hline$m_{1}$ & $-1.911[0.056]$ & ] -1.813 [0.070] & ] $-1.736[0.082]$ & $-1.740[0.082]$ & $-1.746[0.081]$ \\
\hline$m_{2}$ & $-1.073[0.283]$ & ] $-1.037[0.300]$ & ] $-1.131[0.258]$ & $-1.168[0.243]$ & $-1.196[0.232]$ \\
\hline \multirow{10}{*}{$\begin{array}{l}\text { Instrument } \\
\text { matrix }\end{array}$} & size $(2,2)$ & size $(2,2)$ & size $(2,2)$ & size $(2,2)$ & size $(2,2)$ \\
\hline & $\Delta$ size $(1,1)$ & age $(1,1)$ & age $(1,1)$ & age $(1,1)$ & age $(1,1)$ \\
\hline & & $\Delta$ size $(1,1)$ & fown $(1,1)$ & fown $(1,1)$ & fown $(1,1)$ \\
\hline & & Dage $(0,0)$ & $\Delta$ size $(1,1)$ & lev $(1,1)$ & lev $(1,1)$ \\
\hline & & & Dage $(0,0)$ & $\Delta$ size $(1,1)$ & $\operatorname{liq}(1,1)$ \\
\hline & & & $\Delta$ fown $(0,0)$ & Dage $(0,0)$ & $\Delta$ size $(1,1)$ \\
\hline & & & & $\Delta$ fown $(0,0)$ & Dage $(0,0)$ \\
\hline & & & & $\Delta l e v(0,0)$ & $\Delta$ fown $(0,0)$ \\
\hline & & & & & $\Delta l e v(0,0)$ \\
\hline & & & & & $\Delta l i q(0,0)$ \\
\hline
\end{tabular}

Notes: As in Table 2. The underlying sample consists of 20 firms and a total of 111 observations $*$, **, *** Significant at $10 \%, 5 \%$ and $1 \%$ respectively

can enjoy rapid growth. After this point, its average cost curve flattens out and it enters the world of constant average and marginal costs experienced by firms operating above the minimum efficient scale. This finding is consistent with Sutton's (1997) statistical regularities and Geroski's (1995) stylized result for the validity of Gibrat's Law based on evidence from manufacturing holding for the services sector. With respect to serial correlation in proportionate growth rates, factors which make a company grow abnormally fast or slowly can be ascribed to persistence of chance. As in Chesher (1979), one might say that when $\beta$ is not equal to one that size encourages (or discourages) growth and when there is serial correlation in growth rates that growth encourages (or discourages) growth. The estimated coefficient for serial correlation in columns [1] and [2], Table 2, is non-significant and negative. However, when other explanatory variables, related to FDI or financial structure, are included, the serial 
correlation is still negative but becomes significant (at 5\% level). This means that firms with slow growth rates in the past will tend to grow less in the future.

Based on the Evans (1987) and Hall (1987) specification, another regression, reported in columns [2], includes firm age together with size as explanatory variable of firm growth. Table 2, column [2], reports that growth rates are declining with size $(-0.0206)$ and age $(-0.0417)$. Both coefficients (size and age) show a highly significant influence on the firm growth at 1 and $5 \%$ level, respectively. Nevertheless, when financial structure variables are included the coefficient of firm age loses some significance (10\% level). This finding means that smaller and younger firms grow faster than larger and mature firms. With respect to the influence of size, this correlation once again confirms the sub-optimal size of firm, which has to reach the minimum efficient size (MES) to be viable in the market. Small firms must grow faster in relative terms to reach the MES of production in their industry that enables them to survive.

Apart from size and age, industry-specific characteristics related to FDI may have an influence on growth rates. All columns [3] report the results when foreign participation as explanatory variable is added. As reported in Table 2, column [3], a coefficient for foreign participation has the expected positive signal (0.0102) but is statistically insignificant. Like Pfaffermayr and Bellak (2000), we do not find any impact of foreign ownership on firm growth.

Finally, we allow firm-specific characteristics related to financial structure, reported in all columns [4] and [5]. For the whole sample, Table 2, the estimated coefficient for leverage ratio is positive, whilst is negative for liquidity ratio. However, both coefficients are non-significant which means that financial structure has no effect on growth rates. It is important to note that irrespective of specification, the results reveal that Gibrat's Law is always rejected, which means that smaller firms grow faster in the services sector.

By sorting the firms into intervals related to their size, we created two subsamples, one for micro and small firms and other for larger firms. Table 3 reports the results for a sample of micro and small firms, with less than 50 employees, estimated by the GMM-system. As for the whole sample, the GMM-system results, reported in Table 3, show that growth rates are negatively related to firm size and age, which remain statistically significant. The estimated coefficient of foreign participation is positive and non-significant. With respect to financial structure, again we do not find any effect of leverage and liquidity ratios on firm growth. However, the coefficient of liquidity ratio becomes positive. It is also important to note that, the coefficient of past growth is now significant at the $1 \%$ level. If we consider the Heshmati's (2001) classification of micro and small firms, with less than 100 employees, we obtain similar results.

Considering a sample comprising larger firms, with more than 250 employees, estimated by the GMM-system, we find different results. The GMM-system results, reported in Table 4, show that the estimated coefficient for firm size is still significant but has a positive sign. This means that the firm growth path is explosive; firms tend to grow faster as they get larger. The coefficient of firm age has the expected negative sign and is statistically significant, in columns [3] and [4], although very small. Unlike previous results, the coefficient of foreign participation 
is negative but statistically significant. This coefficient improves its statistical significance to the $5 \%$ level when financial structure variables are included. According to this finding, sectors with lower foreign participation appear to grow faster. Lastly, with respect to financial variables the coefficient of leverage ratio has the expected negative sign only in column [4], whilst liquidity is negative (column [5]). It is important to note that financial variables remain non-significant. If we split our sample by age group, we find that the results for younger firms are quite similar to those for micro and small firms.

For each regression and sample, we report the $p$-value of the Wald test of joint significance of the regressors. The joint insignificance of the coefficients included in the regression is clearly rejected by the Wald test.

Arellano and Bond (1991) consider specification tests that are applicable after estimating a dynamic model from panel data by the GMM estimators: a direct test on the second-order residual serial correlation coefficient $\left(m_{2}\right)$ and a Sargan test of over-identifying restrictions. In this context the key identifying assumption that there is no serial correlation in the $\varepsilon_{i t}$ disturbances can be tested by testing for no second-order serial correlation in the first-differenced residuals. The consistency of the GMM estimator depends on the absence of second-order serial correlation in the residuals of the growth specifications. The $m_{1}$ statistics, on the same line as $m_{2}$, tests for lack of first-order serial correlation in the differenced residuals. Another test of specification is a Sargan test of over-identifying restrictions, which has an asymptotic $\chi^{2}$ distribution under the null hypothesis that these moment conditions are valid. Thus, the validity of the dynamic models depends upon a lack of secondorder serial correlation (see the $m_{2}$ statistics) and the validity of the instrument set measured by the Sargan test.

In columns [1] and [2], Table 2, the test statistics indicate that there is evidence of first-but not of second-order serial correlation, whilst in Table 3 no first- and secondorder serial correlation is found. When we introduce other explanatory variables, the $m_{2}$ test gets worse. $m_{2}$ is rejected at the $5 \%$ significance level (but not at the $1 \%$ ) only for the column [3] in Table 2. Thus in Tables 2 and 3, columns [4] and [5] we find some evidence of second-order serial correlation. For the whole sample and for micro and small firms the GMM-system results are consistent only for the growth specifications that include firm size and age. In Table 4, columns [1]-[5], we consider a sample of larger firms (greater than or equal to 250 employees). In this case, we conclude that there is no second order serial correlation. Consequently, the results for this sample are always consistent. Finally, and with respect to the Sargan test, this test is always accepted. This confirms the validity of the instruments chosen. The instruments used are described at the bottom of each table.

\section{Conclusions and implications}

This paper set out to examine if Gibrat's Law can be rejected for the services sector, as it has been for manufacturing, and to analyse the effect of firm and industryspecific characteristics on the growth of firms. For this purpose, an unbalanced panel of 419 Portuguese surviving firms from the services sector was constructed. The 
selection of dynamic growth specifications including serial correlation in the error term motivated the adoption of the panel data techniques developed by Blundell and Bond (1998), in particular the GMM-system, which had not been used previously, as far as we know.

Contrary to Chen and Lu (2003), Piergiovanni et al. (2003), and Audretsch et al. (2004), our estimation results suggest that Gibrat's Law is rejected for different growth specifications and samples of services firms, even when the unobservable firm level heterogeneity is controlled for. Thus the initial number of employees and the past employment growth rate should not be ignored in the explanation of employment growth. The main implication of this finding is that, independent of sector activity, sample, and the methodology used, random influences are not the only reason why firms grow. Like size and past growth, the coefficient of firm age has the expected negative sign and is statistically significant. After controlling for industry and firm-specific characteristics that are likely to impact on firm growth, such as foreign participation and financial structure, we found that these variables do not have any impact on firm growth, with the exception of foreign participation for a sample of larger firms. Thus, we may conclude that size, past growth, and age mostly explain the growth of firms.

The main policy implication that we can draw from these findings is that policy makers should promote the creation and growth of small scale services, because they are becoming chiefly responsible for net job creation.

Acknowledgements We are grateful to Frode Steen, Helen Louri, Christopher Snyder and the participants at the International Industrial Organization Conference (Chicago, 2004), First CEPR School in Applied Industrial Organisation (Hydra, 2004), and 31th European Association for Research in Industrial Economics (Berlin, 2004) for useful comments on an earlier draft. All errors and omissions remain our responsibility.

\section{References}

Arellano M, Bond S (1991) Some tests of specification for panel data: Monte Carlo evidence and an application to employment equations. Rev Econ Stud 58:277-297

Audretsch DB, Klomp L, Santarelli E, Thurik AR (2004) Gibrat's Law: are the services different? Rev Ind Organ 24:301-324

Becchetti L, Trovato G (2002) The determinants of growth for small and medium sized firms. Small Bus Econ 19:291-306

Bellak C (2004) How domestic and foreign firms differ and how does it matter? J Econ Surv 18(4):483-514

Blonigen B, Tomlin K (2001) Size and growth of Japanese plants in the United States. Int J Ind Organ 19:931-952

Blundell R, Bond S (1998) Initial conditions and moment restrictions in dynamic panel data models. J Econom 87:115-143

Caves R (1998) Industrial organization and new findings on the turnover and mobility of firms. J Econ Lit 36:1947-1982

Chen J, Lu W (2003) Panel unit root tests of firm size and its growth. Appl Econ Lett 10:343-345

Chesher A (1979) Testing the Law of Proportionate Effect. J Ind Econ 27:403-411

Cooley T, Quadrini V (2001) Financial markets and firm dynamics. Am Econ Rev 91(5):1286-1310

Das S (1995) Size, age and firm growth in an infant industry: the computer hardware industry in India. Int J Ind Organ 13:111-126

Davis S, Haltiwanger J, Schuh S (1996) Job creation and destruction. The MIT Press, Boston 
Doornik J, Arellano M, Bond S (2002) Panel data estimation using DPD for OX. http://www.nuff.ox.ac. uk/Users/Doornik/

Dunne T, Hughes A (1994) Age, size, growth and survival: UK companies in the 1980s. J Ind Econ 42:115-140

Dunne T, Roberts M, Samuelson L (1988) Patterns of firm entry and exit in US manufacturing industries. RAND J Econ 19:495-515

Dunne T, Roberts M, Samuelson L (1989) The growth and failure of US manufacturing plants. Q J Econ 104:671-698

Elston J (2002) An examination of the relationship between firm size, growth and liquidity in the Neuer Markt. Economic Research Centre of the Deutsche Bundesbank, Discussion paper 15/02

Evans D (1987a) The relationship between firm growth, size and age: estimates for 100 manufacturing industries. J Ind Econ 35:567-581

Evans D (1987b) Tests of alternative theories of firm growth. J Polit Econ 95:657-674

Farinas J, Moreno L (2000) Firms' growth, size and age: a nonparametric approach. Rev Ind Organ 17:249-265

Fotopoulos G, Louri H (2004) Firm growth and FDI: are multinationals stimulating local industrial development? J Ind Competition Trade 4(3):163-189

Geroski P (1995) What do we know about entry? Int J Ind Organ 13:421-440

Geroski P, Lazarova S, Urga G, Walters C (2003) Are the differences in firm size transitory or permanent? J Appl Econom 18:47-59

Gibrat R (1931) Les inégalités économiques. Librairie du Recueil Sirey, Paris

Goddard J, Wilson J, Blandon P (2002a) Panel tests of Gibrat's Law for Japanese manufacturing. Int J Ind Organ 20(3):415-433

Goddard J, Mckillop D, Wilson J (2002b) Credit union size and growth: tests of the Law of Proportionate Effect. J Bank Financ 22:2327-2356

Goddard J, Tavakolli M, Wilson J (2004) Dynamics of growth and profitability in banking. J Money, Credit Bank 36(6):1069-1090

Görg H, Strobl E (2001) Multinational companies and productivity spillovers: a meta-analysis. Econ J 111:723-739

Hardwick P, Adams M (2002) Firm size and growth in the United Kingdom life insurance industry. J Risk Insur 69:577-593

Hall BH (1987) The relationship between firm size and firm growth in US manufacturing sector. J Ind Econ 35:583-606

Harris M, Raviv A (1991) The theory of capital structure. J Financ 46:297-355

Hart PE, Prais SJ (1956) The analysis of business concentration: a statistical approach. J R Stat Soc Ser A 119:150-191

Hart PE, Oulton N (1996) Growth and size of firms. Econ J 106:1242-1252

Hart PE, Oulton N (1999) Gibrat, Galton and job generation. Int J Econ Bus 6:149-164

Heshmati A (2001) On the growth of micro and small firms: evidence from Sweden. Small Bus Econ $17: 213-228$

Jovanovic B (1982) Selection and the evolution of industry. Econometrica 50(3):649-670

Kamshad K (1994) Firm growth and survival: does ownership structure matter? J Econ Manag Strat 3:521-543

Lang L, Ofek E, Stulz R (1996) Leverage, investment, and firm growth. J Financ Econ 40:3-29

Mansfield E (1962) Entry, Gibrat's Law, innovation, and the growth of firms. Am Econ Rev 52:10231051

Markusen J, Venables A (1999) Foreign direct investment as a catalyst for industrial development. Eur Econ Rev 43:335-356

Mata J (1994) Firm growth during infancy. Small Bus Econ 6:27-39

Nurmi S (2003) Plant size, age and growth in Finnish manufacturing. Institute of Fiscal studies, London. http://cemmap.ifs.org.uk/docs/eea_nurmi.pdf

Oulton N (2001) Why do foreign-owned firms in the UK have higher labour productivity? In: Pain, Nigel (ed) Inward investment, technological change and growth: Palgrave. New York, pp 122-161

Pfaffermayr M, Bellak C (2000) Why foreign-owned firms are different? A conceptual framework and empirical evidence for Austria. Hamburg Institute of International Economics, Discussion Paper No. 115

Piergiovanni R, Santarelli E, Klomp L, Thurik AR (2003) Gibrat's Law and the firm size/firm growth relationship in Italian services. Rev d'Economie Industrielle 102:69-82 
Simon H, Bonini C (1958) The size distribution of business firms. Am Econ Rev 48:607-617

Singh A, Whittington G (1975) The size distribution of business firms. Am Econ Rev 48:607-617

Sutton J (1997) Gibrat's legacy. J Econ Lit 35:40-59

Tschoegl A (1983) Size, growth and transnationality among the world's largest banks. J Bus 56:187-201

Tschoegl A (1996) Managerial (dis)economies of scale: the case of regional banks in Japan. Reginald $\mathrm{H}$. Jones Centre for Management Policy Strategy and Organization. University of Pennsylvania, WP, pp 96-104

Ushijima T (2005) Internal capital market and the growth and survival of Japanese plants in the United States. J Jpn Int Econ 19:366-385

Vander Vennet R (2001) The Law of Proportionate Effect and OECD bank sectors. Appl Econ 33:539_ 546

Variyam J, Kraybill D (1992) Empirical evidence on determinants of firm growth. Econ Lett 38:31-36

Wagner J (1992) Firm size, firm growth, and persistence of chance: testing Gibrat's Law with establishment data from Lower Saxony, 1978-1989. Small Bus Econ 4:125-131 